\title{
Biogeochemical cycling in terrestrial ecosystems of the Caatinga Biome
}

\author{
Menezes, RSC. ${ }^{a *}$, Sampaio, EVSB. ${ }^{a}$, Giongo, $V^{b}$ and Pérez-Marin, AM. ${ }^{c}$ \\ ${ }^{a}$ Departamento de Energia Nuclear, Universidade Federal de Pernambuco - UFPE, Av. Prof. Luis Freire, 1000, \\ CEP 50740-540, Recife, PE, Brasil

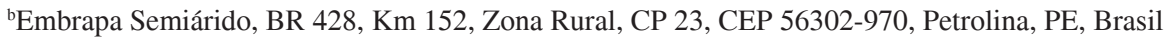 \\ 'Instituto Nacional do Semiárido-MCTI, Centro de Ciências Agrárias - CCA, \\ Universidade Federal de Pernambuco - UFPB, Av. Francisco de Almeida, s/n, Serrotão, \\ CEP 58434-700, Campina Grande, PB, Brasil \\ *e-mail: rmenezes@ufpe.br
}

Received February 13, 2012 - Accepted March 13, 2012 - Distributed August 31, 2012

(With 2 figures)

\begin{abstract}
The biogeochemical cycles of C, N, P and water, the impacts of land use in the stocks and flows of these elements and how they can affect the structure and functioning of Caatinga were reviewed. About half of this biome is still covered by native secondary vegetation. Soils are deficient in nutrients, especially $\mathrm{N}$ and P. Average concentrations of total soil $\mathrm{P}$ and $\mathrm{C}$ in the top layer $(0-20 \mathrm{~cm})$ are $196 \mathrm{mg} \mathrm{kg}^{-1}$ and $9.3 \mathrm{~g} \mathrm{~kg}^{-1}$, corresponding to $\mathrm{C}$ stocks around $23 \mathrm{Mg} \mathrm{ha}^{-1}$. Aboveground biomass of native vegetation varies from 30 to $50 \mathrm{Mg} \mathrm{ha}^{-1}$, and average root biomass from 3 to $12 \mathrm{Mg} \mathrm{ha}^{-1}$. Average annual productivities and biomass accumulation in different land use systems vary from 1 to $7 \mathrm{Mg} \mathrm{ha}^{-1} \mathrm{year}^{-1}$. Biological atmospheric $\mathrm{N}_{2}$ fixation is estimated to vary from 3 to $11 \mathrm{~kg} \mathrm{~N} \mathrm{ha}^{-1}$ year-1and 21 to $26 \mathrm{~kg} \mathrm{~N} \mathrm{ha}^{-1}$ year $^{-1}$ in mature and secondary Caatinga, respectively. The main processes responsible for nutrient and water losses are fire, soil erosion, runoff and harvest of crops and animal products. Projected climate changes in the future point to higher temperatures and rainfall decreases. In face of the high intrinsic variability, actions to increase sustainability should improve resilience and stability of the ecosystems. Land use systems based on perennial species, as opposed to annual species, may be more stable and resilient, thus more adequate to face future potential increases in climate variability. Long-term studies to investigate the potential of the native biodiversity or adapted exotic species to design sustainable land use systems should be encouraged.
\end{abstract}

Keywords: tropical dry forest, nutrient fluxes, carbon, nitrogen, phosphorus.

\section{Ciclagem biogeoquímica em ecossistemas terrestres do Bioma Caatinga}

\begin{abstract}
Resumo
Os ciclos biogeoquímicos de C, N, P e água, os impactos das mudanças do uso da terra nos estoques e fluxos destes elementos e como estas mudanças podem afetar a estrutura e o funcionamento da Caatinga foram revisados. Cerca da metade desse Bioma ainda é coberta por vegetação nativa secundária. Os solos são deficientes em nutrientes, principalmente $\mathrm{N}$ e P. A concentração média, na camada superficial $(0-20 \mathrm{~cm})$, de $\mathrm{P}$ total é $196 \mathrm{mg} \mathrm{kg}^{-1}$, e a de C é $9.3 \mathrm{~g} \mathrm{~kg}^{-1}$, correspondendo a estoques médios em torno de $23 \mathrm{Mg} \mathrm{ha}^{-1}$ de carbono. A biomassa aérea da vegetação varia entre 30 a $50 \mathrm{Mg} \mathrm{ha}^{-1}$, e a biomassa radicular entre 3 a $12 \mathrm{Mg} \mathrm{ha}^{-1}$. As produtividades e acumulações anuais de biomassa nos diferentes usos da terra variam de 1 a $7 \mathrm{Mg} \mathrm{ha}^{-1}$. A fixação biológica de $\mathrm{N}_{2}$ atmosférico é estimada em 3 a $11 \mathrm{~kg} \mathrm{~N} \mathrm{ha}^{-1}$ ano $^{-1}$ e 21 a $26 \mathrm{~kg} \mathrm{~N} \mathrm{ha}^{-1}$ ano $^{-1}$ em Caatinga madura e em regeneração, respectivamente. Os principais processos de perda de nutrientes e água são queimadas, erosão do solo, escoamento e colheita de cultivos e produtos animais. As mudanças climáticas projetadas indicam maiores temperaturas e menores precipitações. Considerando a alta variabilidade intrínseca, ações para aumentar a sustentabilidade deveriam melhorar a resiliência e a estabilidade dos ecossistemas. Sistemas de uso da terra baseados em espécies perenes, em contraposição a anuais, devem ser mais estáveis e resilientes, portanto mais adequados para enfrentar os potenciais aumentos na variabilidade climática. Estudos de longa duração para avaliar o potencial da biodiversidade nativa ou de exóticas adaptadas no delineamento de sistemas de uso sustentáveis deveriam ser encorajados.
\end{abstract}

Palavras-chave: floresta seca tropical, fluxo de nutrientes, carbono, nitrogênio, fósforo. 


\section{General aspects of the caatinga biome}

The Caatinga biome covers a large area in Northeast Brazil, about one million square kilometers, mostly overlapping with the semiarid region. Most of the area of the biome presents average annual rainfall lower than $1000 \mathrm{~mm}$. However, the temporal and spatial variability of rainfall is a marked characteristic of the region (Reddy, 1983), rendering averages of little value. In a simplified picture, $20 \%$ of the annual rainfall occurs in a single day and $60 \%$ in a single month (Sampaio, 1995). Average annual temperatures, on the other hand, are high (23 to $27^{\circ} \mathrm{C}$ ) and relative humidity usually below $50 \%$. As a consequence, the potential evapotranspiration is high, usually above $1500 \mathrm{~mm}_{\text {year }}^{-1}$, resulting in negative water balances along 7 to 11 months every year.

The average altitude is around $400-500 \mathrm{~m}$ but Caatinga reaches the sea in Rio Grande do Norte and Ceará and also covers large plateaus above $1000 \mathrm{~m}$. About $37 \%$ of the area is composed of slopes with 4 to $12 \%$ inclination and $20 \%$ with slopes steeper than $12 \%$, resulting in high erosion risks in cultivated areas (Leprun, 1983). Jacomine (1996) divided the area into three geological types, according to the formation material: 1) areas on top of the crystalline shield; 2) areas where the crystalline shield is covered with sandy material; and 3) areas of sedimentary deposits. Four dominant soil orders, out of a total of 15 orders, form a spatial mosaic covering $66 \%$ of the area (Latosols, $19 \%$; Lithosols, 19\%; Argisols, 15\%; Luvisols, 13\%). Over $80 \%$ of the area has some soil limitation in relation to agricultural use, which may be related to low fertility, shallow profile, poor drainage or high exchangeable $\mathrm{Na}$ (Silva, 2000).

All these climatic and soil variations result in a great diversity of environmental conditions and landscapes. The Caatinga biome spreads over 17 great landscape units, subdivided into 105 geo-environmental units out of a total of 172 for the whole Northeast (Silva et al., 1993). Within this complex region, lives a population of more than 20 million people, making it one of the most densely populated semi-arid regions in the whole world, with 20-30 inhabitants per $\mathrm{km}^{2}$. The land tenure system, in which $80 \%$ of farms are smaller than 10 ha, creates a condition of extreme vulnerability of the population to climate variability (Sampaio et al., 2009). Therefore, the frequent droughts that occur usually lead to severe negative impacts on the population, the economy and natural resources of the region.

\subsection{Main land use systems in the Caatinga biome}

The area annually occupied with agricultural fields comprises about $10 \%$ of the whole semiarid region (Sampaio and Menezes, 2002). Less than 2\% are permanent crops and most of the annual crops are planted in the slash and burn system. Livestock, mainly cattle but also goats and sheep, are ubiquitous. Native pastures covered $13 \times 10^{6}$ ha, while planted pastures covered $6 \times 10^{6}$ ha (Sampaio and Salcedo, 1997). However, cattle also feed on the harvested agricultural fields and fallow vegetation and mature Caatinga areas. In the 1990 's, fuel wood extraction was the main driver for the annual deforestation of about $1 \times 10^{6}$ ha, only in the states of CE, RN, PB and PE (Sampaio and Salcedo, 1997) and the area deforested due to wood extraction has been growing since then. At that time, most of the wood came from new agricultural fields but now it is mostly an independent activity. In the whole region, according to Araújo Filho and Barbosa (2000), the annual deforestation reaches $2.7 \%$ of the area and more than $80 \%$ of the native vegetation cover corresponds to pioneer and secondary vegetation stages.

\subsection{Remaining area of native vegetation}

In 1984, native Caatinga vegetation covered $68 \%$ of its original area, the rest being used for agriculture or greatly altered by anthropic activities (CNRBC, 2004). In 1990, an updated survey conducted by Sudene and Ibama indicated an expressive reduction of the native coverage, to $47 \%$. In 2004, results from 'Projeto de Conservação e Utilização Sustentável da Diversidade Biológica Brasileira' (Probio) showed only a small decrease in this area (to $43 \%$ ), corresponding to $363115 \mathrm{~km}^{2}$. Monitoring in 2008, performed using 111 orbital images from CBERS2B and 52 images from TM Landsat 5, estimated the coverage to be $53.6 \%$ (Figure 1). It is possible that most of the difference in the more recent survey resulted from a difference in the methodological approach and not from a real increase in coverage. In a complex mosaic of vegetation with distinct regeneration ages and growth potential due to different environmental characteristics it is difficult to determine

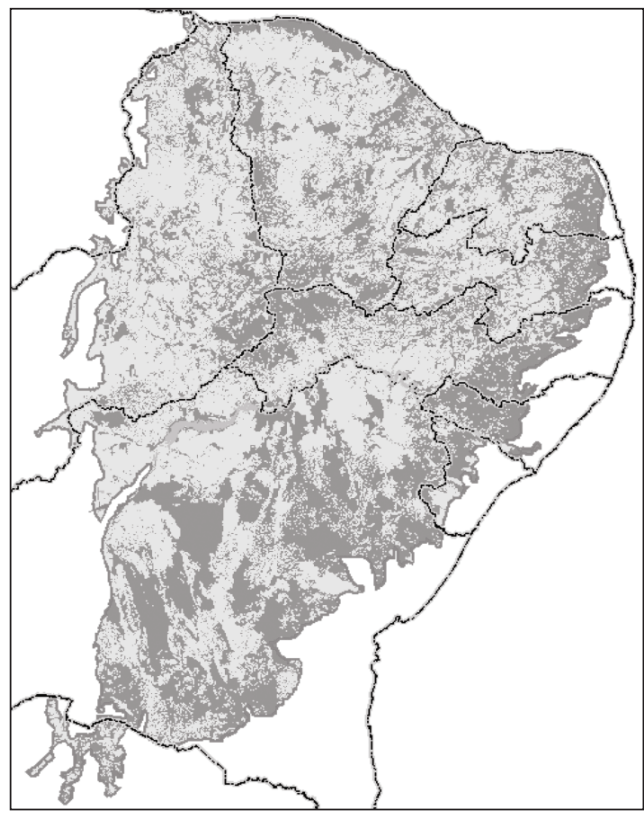

Figure 1. Native vegetation (lighter color) and deforested darker color covered areas in the Caatinga biome, in 2008. Source: Brasil - Ministério do Meio Ambiente, 2010. 
the limits of native vegetation, but it is also possible that the area of native vegetation has had an increase due to the recent socio-economic changes that occurred in the region and in Brazil.

\section{Structure and functioning of terrestrial ecosystems}

Due to the high demographic density (20 to 30 inhabitants per $\mathrm{km}^{2}$ ) and the land tenure system, most of the semiarid region of NE Brazil has been subdivided into a large number of small properties, with less than 10 ha each. This high pressure pushed the region beyond its sustainability limit. Irrigation and high input systems are limited to at the most $3 \%$ of the area due to low water availability plus soil inadequacy (Sampaio et al., 2009). Therefore, low input systems, subjected to the high climatic variability and characterized by instability of their biogeochemical processes are the rule. Understanding the functioning of these systems requires knowledge of these processes, in order to identify practices capable of increasing regional sustainability.

Figure 2 shows a conceptual model of the main stocks and flows of carbon, water and nutrients in a typical agroecosystem in the Caatinga biome. The main objective of this paper is to present the available information on these stocks and flows. Flows are colored according to their impact on the balance of nutrients: blue are inputs and red are outputs from the system. To maintain productivity, inputs should be maximized and outputs minimized. Green flows indicate recycling and should be managed so as to increase productivity in a sustainable way. The uptake flow from deeper soil layers (dotted line) assumes that resources (water and nutrients) may be tapped in systems with trees or deep rooted perennial grasses and shrubs.

\section{Carbon and nutrient stocks in soils and vegetation}

\subsection{Carbon and nutrient stocks in soils}

Average total organic carbon (TOC) in the Ap horizon of soils under Caatinga vegetation are generally low, compared to other biomes of Brazil (Table 1). These low values are related primarily to the low organic residue inputs and to the low vegetal biomass formation, which is limited by water and also soil fertility deficiencies.

Table 2 presents more detailed soil data obtained from the surveys of all Northeastern states, except Maranhão and Piaui (Jacomine et al., 1971; 1972a, b; 1973; 1975 $\mathrm{a}, \mathrm{b} ; 1979)$. Among the soil orders that occur in the region, Vertisols and Cambisols have the highest TOC $\left(12,3 \mathrm{~g} \mathrm{C} \mathrm{kg}^{-1}\right)$ but occupy only $5 \%$ of the semiarid area. Luvisols and Lithosols occupy a larger area (32\%), mainly on top of the crystalline shield and have TOC between 10.4 e $11.8 \mathrm{~g} \mathrm{~kg}^{-1}$. Latosols and Argisols follow in area (36\%), the first ones mainly derived from sedimentary and the second ones from both crystalline and sedimentary material, and have TOC between 9.7 and $8.9 \mathrm{~g} \mathrm{~kg}^{-1}$.

Table 1. Soil organic carbon stock in areas under native vegetation or anthropic use in Brazilian biomes.

\begin{tabular}{|c|c|c|}
\hline \multirow[t]{2}{*}{ Biome } & $\begin{array}{c}\text { Native } \\
\text { vegetation }\end{array}$ & Anthropic use \\
\hline & \multicolumn{2}{|c|}{ Mg ha $^{-1}$} \\
\hline Amazon & 29.08 & 33.35 \\
\hline Caatinga & 23.68 & 22.27 \\
\hline Cerrado & 39.17 & 33.52 \\
\hline Atlantic forest & 41.85 & 37.51 \\
\hline
\end{tabular}

Source: Adapted from Chagas et al. (2004) and Fidalgo et al. (2007).



Figure 2. Conceptual model of the main stocks and flows of C, N, P and water in agroecosystems of the Caatinga biome. Flows in gray color represent inputs, those in dashed black lines represent outputs from the system, while those in solid black lines represent internal cycling (adapted from Menezes et al., 2005). 
Menezes et al. (2005) compiled data from several soil surveys and reported that $90 \%$ of the soil samples of the main orders in the semiarid region of NE Brazil had medium to low extractable $p$ levels. Total $p$ is generally higher in Luvisols and Lithosols than in Latosols and Argisols (Table 2). In general, there is a close relation among TOC and total $\mathrm{P}\left(\mathrm{r}=0,89^{* *}\right)$ and TOC and clay content $\left(\mathrm{r}=0,82^{* *}\right)$. The lowest TOC and total $\mathrm{p}$ values are those of Regolithic Neosols, which frequently receive manure additions when cultivated, due to the extremely low fertility.

Information regarding stocks and availabilities of $\mathrm{N}$, $\mathrm{P}$ and other nutrients in soils of the Caatinga biome are relatively scarce, but the available studies are consistent in pointing $\mathrm{N}$ and $\mathrm{P}$ as the most limiting to plant growth. Cavalcanti et al. (1998) and Guimarães et al. (1998) published surveys of fertility analysis for soils of Pernambuco and Ceará, respectively. Sampaio et al. (1995) reviewed some of the earlier works, including the first approximation of Galvão and Cate Junior (1969) for Rio Grande do Norte, Paraíba, Pernambuco and Alagoas and the evaluation of Oliveira et al. (1988) for the whole Northeast region. They are based on thousands of soil samples and indicate a general deficiency of $\mathrm{P}$ and low need for liming, except for Piauí and, in a smaller scale, for Alagoas. This broad panorama confirms that $\mathrm{N}$ and $\mathrm{P}$ are limiting and that practices to raise soil fertility are needed in the region.

\subsection{Aboveground biomass of perennial vegetation}

The average aboveground biomass of Caatinga vegetation has been estimated to be in the interval between 30 and $50 \mathrm{Mg} \mathrm{ha}^{-1}$. A better approximation cannot be made because direct measurements are almost non-existent, indirect estimations reveal a very high spatial variability (2 to $156 \mathrm{Mg} \mathrm{ha}^{-1}$ ) and the sampled areas are few and chosen according to preferential criteria. Direct measurement (74 $\mathrm{Mg} \mathrm{ha}^{-1}$ ) was made in a single site at Serra Talhada, Pernambuco (Kauffman et al., 1993). Estimates based on botanical surveys tend to fall in the upper part of the range because of the preference for undisturbed vegetation while estimates based on fuel wood production tend to fall in the lower part of the range because they include areas with repeated short cycle (10 to 15 years) clear cutting (Gariglio et al., 2010). Since most of the Caatinga corresponds to vegetation recovering from previous cutting, for fuel wood or part of the slash and burn agriculture system, the regional average must be in the lower third of the range. Of the total aboveground biomass, 5 to $10 \%$ (2 to $6 \mathrm{Mg} \mathrm{ha}^{-1}$ ) correspond to leaves (Table 3) and are renewed every year, contrasting with the biomass stocked in stems and branches (Silva, 1998). Most of this leaf biomass is consumed by the ubiquitous domestic herds, either directly from the plants or after falling to the ground (Schacht et al., 1989; Hardesty and Box, 1988).

Data for cultivated areas are fewer than for Caatinga. The area with perennial crops is proportionally small. The only available data is for five year old dwarf cashew plants (Table 3). Other perennial crops, like Prosopis juliflora and Gliricidia sepium, probably have biomasses in the upper range of Caatinga, since they are usually planted in sites with more water availability. The aboveground biomass of annual crops is considered as production and it is eliminated every year, exported as agricultural product, consumed by animals, burned or incorporated to the soil.

\section{Processes that promote carbon and nutrient inputs to ecosystems}

\subsection{Annual aboveground net primary productivity}

Papers dealing with annual biomass productivity are scarcer in the literature than those that quantified biomass stocks in the Caatinga biome. The variation is very large due to the enormous variability of water availability, brought about by rainfall variation, topographic differences and different soil depth and water holding capacities (Menezes and Sampaio, 2000). Annual productivities and biomass accumulation are estimated to vary from 1 to $7 \mathrm{Mg} \mathrm{ha}^{-1}$ year-1 $^{-1}$ and all actual measurements fall in this range (Table 3 ). This capacity can be expressed as years necessary to rebuild the stocks. The sustainable cycle of fuel wood production has been estimated to vary from 10 to 15 years, with average of 13 years (Gariglio et al.,

Table 2. Characteristics of the Ap horizon of the main soil orders in the Caatinga biome.

\begin{tabular}{|c|c|c|c|c|c|c|}
\hline \multirow{2}{*}{ Soil order ${ }^{2}$} & \multirow{2}{*}{$\mathbf{N}$} & \multirow{2}{*}{$\begin{array}{c}\text { Depth } \\
\text { cm }\end{array}$} & TOC & Clay & Silt & \multirow{2}{*}{$\begin{array}{c}\text { Total P } \\
\text { mg kg }^{-1}\end{array}$} \\
\hline & & & & $\mathrm{g} \mathrm{kg}^{-1}$ & & \\
\hline Vertisol (1\%) & 16 & 13.1 & 12.3 & 374 & 238 & 368 \\
\hline Cambisol (4\%) & 13 & 12.4 & 12.2 & 295 & 212 & 301 \\
\hline Luvisol (13\%) & 47 & 13.7 & 11.8 & 176 & 258 & 235 \\
\hline Lithosol (19\%) & 45 & 17.6 & 10.4 & 132 & 250 & 239 \\
\hline Latosol $(21 \%)$ & 41 & 15.6 & 9.7 & 250 & 130 & 173 \\
\hline Argisol (15\%) & 90 & 15.3 & 8.9 & 147 & 157 & 167 \\
\hline Planosol (4\%) & 68 & 18.2 & 7.4 & 105 & 188 & 162 \\
\hline Regolithic neosol (4\%) & 20 & 16.5 & 4.9 & 37 & 105 & 99 \\
\hline Weighted average (3) & 340 & 15.9 & 9.3 & 163 & 189 & 196 \\
\hline
\end{tabular}

1) Source: Jacomine et al. (1971, 1972a, b, 1973, 1975a, b, 1977). 2) Percentages correspond to proportion in relation to the area of the Northeastern semiarid. 3) Weighted average according to the number of samples in each soil order. 
Table 3. Biomass stocks and production in perennial crop areas or areas with native Caatinga vegetation.

\begin{tabular}{|c|c|c|c|c|}
\hline & $\begin{array}{c}\text { Stock } \\
\text { Mg ha-1 }^{-1}\end{array}$ & Reference & $\begin{array}{c}\text { Production } \\
\mathrm{Mg} \mathrm{ha}^{-1} \text { year }^{-1}\end{array}$ & Reference \\
\hline \multicolumn{5}{|c|}{ Caatinga } \\
\hline Total aboveground & $30-50$ & $1,2,3,4$ & $1-7$ & $5,6,7$ \\
\hline Leaves & $2-6$ & 1,2 & - & \\
\hline Litterfall & - & & $2-6$ & $8,9,10,11$ \\
\hline Ground bromélias & 1.4 & 12 & - & \\
\hline Herbs & $0.2-4$ & $6,13,14,15$ & $0.2-4$ & $6,13,14,15$ \\
\hline Roots & $4-12$ & 16,17 & 2.4-4.4 & 18,19 \\
\hline \multicolumn{5}{|c|}{ Crops } \\
\hline Dwarf cashew crop & $9-15$ & 20 & - & \\
\hline $\begin{array}{l}\text { Weeds below } \\
\text { cashew trees }\end{array}$ & $1-6$ & 21,22 & - & \\
\hline Residues in agroforests & - & & $1-5$ & 23 \\
\hline Residues in annual crops & - & & $0.3-6$ & 24 \\
\hline
\end{tabular}

1) Silva (1998); 2) Kauffman et al. (1993); 3) Costa et al. (2002); 4) Amorim et al. (2005); 5) IBAMA (1992); 6) Sampaio et al. (1998); 7) Menezes and Sampaio (2000); 8) Dantas (2003); 9) Santana (2005); 10) Schacht et al. (1989); 11) Hardesty and Box (1988); 12) Albuquerque and Bandeira (1995); 13) Lima et al. (1985); 14) Silva et al. (1995); 15) Albuquerque and Bandeira (1995); 16) Salcedo et al. (1999); 17) Tiessen et al. (1992); 18) Leite (1998); 19) Medeiros (1999); 20$)$ Morais et al. (2004); 21) Ribeiro et al. (2004); 22) Maia et al. (2004a); 23) Maia et al. (2004b); 24) Sampaio et al. (2004).

2010). The length of the fallow period allowing sufficient nutrient accumulation in the aboveground biomass and the re-initiation of the slash and burn cycle is in this same range. In Araripina, Pernambuco, the fallow period was 12 years (Tiessen et al., 1992). However, the large variability of climate, soil fertility and previous level of soil degradation renders general averages of little value.

Herb and small shrub biomass stocks and productions have similar values ( 2 to $6 \mathrm{Mg} \mathrm{ha}^{-1}$ year $^{-1}$ ) because most of these plants have annual cycles. Bromelias and small cacti are exceptions. Production values are also similar to those of trees and large shrubs and are inversely related to the biomass stock of these large plants: areas of Caatinga vegetation with tall and dense canopies produce little biomass of small plants and the opposite occurs in areas of open Caatinga vegetation, except if they are in degraded or environmentally limited areas. Selective cutting of plants to reduce density and shading is a management technique used to increase pasture production. One single estimate was made of bromeliad biomass $\left(1.4 \mathrm{Mg} \mathrm{ha}^{-1}\right)$ which is very dense in some areas but absent in other ones (Table 3 ). Within fields of perennial crops, the biomass of weeds has the same variation as that in native vegetation, depending on size and density of the crop plants, except after weeding or herbicide application (Ribeiro et al., 2004).

Many publications refer to annual crops, largely dominant in the semiarid, but most have data only about the commercial products (fruits, foliage, etc) and very few include data on total biomass, in spite of the importance of crop residues as animal fodder. Productions vary greatly ( 0.2 to $\left.6 \mathrm{Mg} \mathrm{ha}^{-1} \mathrm{year}^{-1}\right)$ but, except in irrigated areas, are similar to those of native plants or even smaller, under similar environmental conditions, due to their inferior adaptability, lower biodiversity and shorter life cycle.

\subsection{Litter deposition}

Data about litter deposition and decomposition in areas of Caatinga vegetation are still scarce in the literature (Sampaio and Silva, 1996). Among the few studies conducted, we may mention Dantas (2003), Santana (2005), Souto (2006), and Costa et al. (2007). On average, litter production in the drier areas of the Caatinga biome falls between 1500 to $3000 \mathrm{~kg} \mathrm{ha}^{-1}$ year ${ }^{-1}$, on a dry matter basis, but may reach over $6000 \mathrm{~kg} \mathrm{ha}^{-1}$ year-1 $^{-1}$ in the more humid areas of the region (Sampaio and Silva, 1996; Dantas, 2003). These levels of litter production are clearly lower than those observed in other forest formations in Brazil but, similarly to other ecosystems, the period of peak litterfall in areas of Caatinga vegetation occurs at the end of the rainy season and beginning of the dry season.

Data about litter stocks are also rare. Martins (2008) quantified the stocks of litter in areas of Caatinga in Pernambuco and found 6,500 to $20,100 \mathrm{~kg} \mathrm{ha}^{-1}$ of dry matter in preserved areas, from 1,900 to $7,200 \mathrm{~kg} \mathrm{ha}^{-1}$ in moderately degraded areas, and from 140 to $1.016 \mathrm{~kg} \mathrm{ha}^{-1}$ in severely degraded areas. Amorim (2009) studied the carbon cycling in an area of preserved Caatinga in Petrolina, Pernambuco, and observed an average litter stock of $7,000 \mathrm{~kg} \mathrm{ha}^{-1}$. In another study in an area of Caatinga in Paraíba, Souto (2006) estimated an average litter stock of about $1,200 \mathrm{~kg} \mathrm{ha}^{-1}$.

Most of the Caatinga litter biomass corresponds to the leaf fraction, followed by bark, branches and the miscellaneous fractions (Souto, 2006). The nutrient content of the leaf fraction has been reported by Dantas (2003), who found average values of $19.1 ; 1.0 ; 15.6 \mathrm{~g} \mathrm{~kg}^{-1}$ of $\mathrm{N}, \mathrm{P}$ and $\mathrm{K}$, on a dry matter basis, respectively, while Santana (2005) observed concentrations of 14.5; 0.8 ; and $7.6 \mathrm{~g} \mathrm{~kg}^{-1}$ of these elements. 


\subsection{Root biomass stocks and productivity}

Only four papers deal with root biomass of native vegetation in the Caatinga biome, two restricted to thin roots in the upper soil layer. The stock of $5 \mathrm{~mm}$ thick roots down to $30 \mathrm{~cm}$ soil depth varied from 3 to $8 \mathrm{Mg} \mathrm{ha}^{-1}$ in Caruaru, PE (Salcedo et al., 1999), while the total stock down to $1 \mathrm{~m}$ reached $12 \mathrm{Mg} \mathrm{ha}^{-1}$ in Araripina, PE (Tiessen et al., 1992).

The production of thin roots (up to $2 \mathrm{~mm}$ thick) in the top soil layer, estimated as the stock difference along the year, was 2.4 Mg ha ${ }^{-1}$ year $^{-1}$ (Medeiros, 1999). Therefore, the magnitude seems to be the same as that of aboveground biomass productivities. In a 5 year old dwarf cashew crop, roots down to $30 \mathrm{~cm}$ soil depth had biomass ( 0.5 to $0.9 \mathrm{Mg} \mathrm{ha}^{-1}$ ) corresponding to less than $10 \%$ of the aboveground biomass (Morais et al., 2004).

\subsection{Atmospheric deposition of nutrients}

Nutrient inputs through rainfall are one of very few processes that provide nutrients to ecosystems in the Caatinga biome. In spite of its low magnitude, this input becomes relevant because of the low natural stocks and the low inputs of other external sources. Perez-Marin and Menezes (2008) quantified nutrients in rainfall water in an agroforestry system and evaluated the effects of tree canopies in the nutrient content of the water reaching the soil. Those authors determined that $32 \%$ of the total rainfall (TR) was intercepted by the canopies (I), $67 \%$ passed as throughfall (T) and only 0.74 reached the soil through stemflow (S). Stemflow only occurred during rain events equal to or larger than $4 \mathrm{~mm}$, a similar value to that reported by Lima and Leopoldo (2000) in a riparian forest $(4.2 \mathrm{~mm})$. Although low, the quantities of $\mathrm{S}$ are relevant because the water reaches the soil at a low speed and are more easily infiltrated, resulting in a localized water and nutrient distribution around the trees (Oliveira Junior and Dias, 2005; Johnsson, 1990). The concentrations of $\mathrm{N}$ and $\mathrm{P}$ in $\mathrm{S}$ and $\mathrm{T}$ were similar and four times higher than those of the rainwater. The concentration of $\mathrm{K}$ was 2 times higher in $\mathrm{S}$ than in $\mathrm{T}$ and seven times higher than in the rainwater. Average $\mathrm{N}, \mathrm{P}$ and $\mathrm{K}$ inputs were 5,1 and $24 \mathrm{~kg} \mathrm{ha}^{-1}$ in the rainwater, 9,2 and $62 \mathrm{~kg} \mathrm{ha}^{-1}$ in the throughfall and $0.12,0.02$ and $1 \mathrm{~kg} \mathrm{ha}^{-1}$ in stemflow water, respectively.

\subsection{Biological nitrogen fixation}

The capacity of Caatinga legume species to simbiotically associate with rhizobia is an important issue to their use in agroforestry systems and revegetation programs. However, knowledge on the subject is limited in semiarid Northeast in spite of the high number of total legume species, many of them endemic (Queiroz, 2002). The world literature on legume nodulation (Allen and Allen, 1981; The Bean Bag, 1995, 1996, 1997, 2002; Souza et al., 1994; Faria et al., 1984, 1987, 1989; Faria and Lima, 1998) refer to approximately 293 species that occur in the semiarid, $216(73.4 \%)$ nodulate, $69(23.5 \%)$ do not and 8 species have conflicting information.
In general, $\delta^{15} \mathrm{~N}$ of tropical forests are higher than those of temperate forests (Martinelli et al., 1999). Values of nonfixing species in Caatinga ( 7 a 9\%o) are high (Freitas et al., 2010a) compared to those of other Brazilian ecosystems: cerrado, <2\%o (Sprent et al., 1996; Bustamante et al., 2004); and Amazon forest, $<5,25 \%$ (Gehring et al., 2005). But they are similar to those found by Schulze et al. (1991) in semiarid areas of Namibia (7.38\%o). A survey of determinations in 118 areas indicates that high values are usually associated with semiarid regions (Handley et al., 1999). The processes that increase $\delta^{15} \mathrm{~N}$ signals are associated to soil mineral $\mathrm{N}$ losses, usually through leaching or volatilization. Any factor that increases the flow from organic to mineral pools (more susceptible to losses) drives the systems to enrichment of ${ }^{15} \mathrm{~N}$ (Högberg, 1997; Handley et al., 1999).

In Caatinga, trees with high $\mathrm{N}_{2}$ fixation can be clearly separated from non-fixing ones based on their $\delta^{15} \mathrm{~N}$ signals. Several species have been identified as fixing high proportions of their $\mathrm{N}$ while others are clearly non-fixing ones (Freitas et al., 2010b; Souza, 2010). Preliminary estimates of $\mathrm{N}$ amounts fixed annually in the canopy of Caatinga were made for two sites: in Serra Talhada, PE, they were of $3 \mathrm{~kg} \mathrm{ha}^{-1}$, in mature Caatinga, and $26 \mathrm{~kg} \mathrm{ha}^{-1}$ in a regenerating Caatinga; in Remigio, $\mathrm{PB}$, they were 11 and $21 \mathrm{~kg} \mathrm{ha}^{-1}$, respectively (Freitas and Sampaio, 2008). To these amounts must be added the amounts fixed in the wood parts that were estimated only for the regenerating Caatinga in Serra Talhada $\left(22 \mathrm{~kg} \mathrm{ha}^{-1}\right)$. Apparently, the contribution of biological fixation to mature Caatingas is small but it is, of the same order of magnitude of the only other estimative ( $7 \mathrm{~kg} \mathrm{ha}^{-1}$ year $^{-1}$ Roggy et al. 1999), found in the literature for a tropical vegetation, a rain forest in French Guyana (Roggy et al. ${ }^{1}$ 1999). The most important factor for these low amounts is the low proportion of plants of fixing species in the mature vegetation, a fact confirmed by several studies (Sampaio, 1996). In regenerating Caatinga, the large difference comes from the much higher proportion of fixing plants.

\section{Processes that lead to losses of water, $\mathrm{C}, \mathrm{N}$ and $P$}

\subsection{Losses due to the removal of Caatinga vegetation}

Slash-and-burn systems, which still exist in the Caatinga biome, contribute significantly to losses of carbon and nutrients from agroecosystems. However, in NE Brazil, the agricultural phase of the slash-and-burn cycle is losing the significance as the main driver of land clearing, due to the low prices and low productivities of crops in the region. Instead, the extraction of fuel wood, in many areas of the region, is becoming the main driver of deforestation, in order to supply the widespread domestic, commercial and industrial demands for fuel wood in the region.

The fire used after land clearing eliminates the debris (small branches and leaves) and also promotes a short-term improvement in soil fertility, due to inputs of nutrients in the ash and the elimination of the seed bank of many invasive 
plant species. However, the fire also leads to the loss of almost $100 \%$ of the $\mathrm{C}$ and $\mathrm{N}$ and part of the $\mathrm{P}$ present in the burnt biomass. Kauffman et al. (1993) quantified losses of more than 500 and $20 \mathrm{~kg} \mathrm{ha}^{-1}$ of $\mathrm{N}$ and $\mathrm{P}$, respectively, after a fire to burn the biomass slashed from an area of Caatinga in Serra Talhada, PE.

In addition to the losses from the slashed vegetation, the fire may also lead to significant losses of $\mathrm{C}$ and $\mathrm{N}$ from soil organic matter. Salcedo et al. $(1993,1997)$ worked in the same plots as Kauffman et al. (1993) and observed rapid decreases in nutrient stocks in the soil organic matter during the months following slash and burn. Similarly, Tiessen et al. (1992), who worked in an Oxisol in Araripina, PE, found losses up to $40 \%$ of soil C only six years after land clearing. In another study, Fraga and Salcedo (2004) quantified the stocks of $\mathrm{C}$ and organic $\mathrm{N}$ and $\mathrm{P}$ in ten sites in Paraíba and Pernambuco, comparing soils under native Caatinga vegetation and adjacent agricultural or pasture plots. Those authors found that the cultivated areas had only approximately half of the levels of carbon and nutrients compared to the soils under Caatinga.

\subsection{Nutrient outputs due to crop harvest and grazing}

After mineralization, the nutrients in the soil organic matter are converted to labile forms and may be taken up by crops or forage species. Afterwards, a fraction of these nutrients is then exported from the ecosystem due to the sale of crops or animal products. Menezes et al. (2002) quantified the removal of nutrients from subsistence systems in family farms in the semi-arid region of Paraíba and found that cropping fields lost, on average, 16, 1 and $18 \mathrm{~kg} \mathrm{ha}^{-1}$ year $^{-1}$ of $\mathrm{N}, \mathrm{P}$ and $\mathrm{K}$, respectively, due to the harvest of grains and straw. The results are similar to those reported by Sanchez (2002), which compiled 30 years of data from 37 countries in Africa and found average N, P and $\mathrm{K}$ losses of 22, 2.5 and $15 \mathrm{~kg} \mathrm{ha}^{-1} \mathrm{year}^{-1}$ from cropping fields. In another study, Menezes et al. (2005) quantified the removal of nutrients in the biomass of prickly pear (Opuntia ficus-indica Mill) cultivated to be used as forage in 50 fields in semi-arid NE Brazil. Since this species is particularly productive in dry lands, nutrient removal was extremely high, averaging up to 300,107 and $1454 \mathrm{~kg} \mathrm{ha}^{-1}$ of $\mathrm{N}, \mathrm{P}$ and $\mathrm{K}$, respectively, in the 5 most productive fields, which represented 7 and $3 \%$ of the total $\mathrm{N}$ and $\mathrm{P}$ from the top layer of the soils.

\subsection{Losses due to soil erosion and water runoff}

In addition to the losses due to mineralization and nutrient removal in the harvested crops and pastures, soil erosion is also one of the main processes responsible for the soil fertility decreases in the Caatinga biome (Menezes e Sampaio, 2002; Sampaio et al., 1995). Studies about soil losses following the conversion of native vegetation into cropping fields or pastures present alarming data about these processes (Albuquerque et al., 2001; Margolis et al., 1985b). The severe soil losses reported due to land use change are also related to great water losses due to runoff and, as a consequence, to lower water infiltration and lower water availability for plant growth. The severe rates of erosion and runoff in agroecosystems of the Caatinga biome are a result of the combination of the relief, with most soils presenting moderate to severe slopes, and the rainfall pattern, characterized by short, but intense rainfall events (Sampaio et al., 1995).

The influence of the soil cover type on soil erosion in the Caatinga biome is well reported in the study conducted by Albuquerque et al. (2001). These authors conducted an 8-year study in which quantified soil losses in large field plots with different land covers (native vegetation, crops or pastures) and observed average soil losses of 3 and $30 \mathrm{t} \mathrm{ha}^{-1}$ year $^{-1}$ in pastures and cropping fields, respectively, while losses under native vegetation averaged only $0,1 \mathrm{t} \mathrm{ha}^{-1}$ year $^{-1}$. This study also reported data on the inter-annual variability of these processes, demonstrating that $40 \%$ of the soil losses occurred in a single year and other $50 \%$ in three other years. In another study, Fraga and Salcedo (2004) used the ${ }^{137} \mathrm{Cs}$ technique to estimate soil erosion during a 35-year period after removal of the native Caatinga to implement pastures or cropping fields and estimated that during that period, $57 \%$ of the $\mathrm{C}$ and $\mathrm{N}$ lost from the soil in the deforested areas were due to mineralization, while the remaining $43 \%$ were due to soil erosion (up to $500 \mathrm{t} \mathrm{ha}^{-1}$ of soil loss during the whole period). Therefore, it is evident the need for the implementation of soil management and conservation practices in agroecosystems of the Caatinga biome in order to avoid soil erosion and the severe depletion of carbon and nutrients after the removal of the native vegetation. Studies that evaluated the impacts of the implementation of soil management practices, such as terraces, countour planting, construction of countour barriers vegetation or stones, etc, have reported 80 to $100 \%$ reductions of soil losses compared to reference areas (Silva et al., 1986; Margolis et al., 1985a; Freitas et al., 1981).

\section{Potential impacts of future land use and climate variability}

The environmental degradation in many areas of the Caatinga biome has been classified as desertification, which may strongly affect biogeochemical cycling in the region. The desertification processes have both anthropogenic and natural drivers. As discussed previously, the human induced degradation is mostly rooted on deforestation and inadequate soil management, such as slash-and-burn systems, overgrazing and intensive fuel wood extraction. Soil erosion processes are also important drivers of desertification in the Caatinga biome, since it decreases soil fertility and water availability, affecting most ecosystem processes.

Nowadays, there are about $1,300,000 \mathrm{~km}^{2}$ of land in the biome that are susceptible to desertification, which include areas within 1,488 municipalities of nine Brazilian states (Brasil, 2007). It is evident, therefore, the need for the establishment of actions to prevent deforestation, to improve soil management techniques, and to develop sustainable land use systems in the biome. It is also 
important to mention that the success of such actions will depend on effective long-term commitment from the many agencies and institutions related to this issue, both at the federal, state and municipal levels.

In addition to unsustainable land use practices, future changes in climate patterns also have strong potential to cause significant impacts in the biogeochemical cycles in the Caatinga biome. In fact, among all biomes in Brazil, the Caatinga is the one with the strongest projected impacts related to climate change. Higher temperatures, lower amounts and increased variability in precipitation patterns are some of the expected changes in the region, which may lead to more intense and frequent droughts, floods, biodiversity loss and lower production of food and energy generation (Brasil, 2004).

\section{References}

ALBUQUERQUE, AW., LOMBARDI NETO, F. and SRINIVASAM, VS., 2001. Efeito do desmatamento da Caatinga sobre as perdas de solo e água de um Luvissolo em Sumé (PB). Revista Brasileira de Ciência do Solo, vol. 25, p. 121-128.

ALBUQUERQUE, SG. and BANDEIRA, GRL., 1995. Effect of thinning and slashing on forage phytomass from a caatinga of Petrolina, Pernambuco, Brazil. Pesquisa Agropecuária Brasileira, vol. 30, p. 885-891.

ALLEN, ON. and ALLEN, EK. 1981. The leguminosae: a source book of characteristics use and nodulation. Wisconsin: University of Wisconsin Press. 812 p.

AMORIM, IL., SAMPAIO, EVSB. and ARAÚJO, EL., 2005. Flora e estrutura da vegetação arbustivo-arbórea de uma área de caatinga do Seridó, RN, Brasil. Acta Botanica Brasilica, vol. 19 , p. 615-623.

AMORIM, LB., 2009. Caracterização da serrapilheira em caatinga preservada e mudanças no carbono do solo após o desmatamento sem queima. Recife: Universidade Federal Rural de Pernambuco. 62 p. Dissertação de Mestrado em Ciência do Solo.

ARAÚJO FILHO, JA. and BARBOSA, TML., 2000. Manejo agroflorestal da caatinga: uma proposta de sistema de produção. In OLIVEIRA, TS., ROMERO, RE., ASSIS JUNIOR, RN. and SILVA, JRCS. (Eds.). Agricultura, sustentabilidade e o semiárido. Fortaleza: Sociedade Brasileira de Ciência do Solo; Universidade Federal do Ceará. p. 47-57.

Brasil. Ministério do Meio Ambiente - MMA, 2004. Programa de Ação Nacional de Combate à Desertificação e Mitigação dos Efeitos da Seca, PAN-BRASIL. Brasília: MMA. 225 p.Edição Comemorativa dos 10 anos da Convenção das Nações Unidades de Combate à Desertificação e Mitigação dos Efeitos da Seca - CCD.

Brasil. Ministério do Meio Ambiente - MMA, 2007. Programa de Conservação e Utilização Sustentável da Diversidade Biológica Brasileira - PROBIO. Available from: <http://www.mma.gov. br/>. Access in: set. 2010.

Brasil. Ministério do Meio Ambiente - MMA. Secretaria de Biodiversidade e Florestas, 2006. Mapas de cobertura vegetal dos Biomas Brasileiros. Available from: <http://www.mma.gov.br/sitio/ index .php?ido $=$ conteudo monta\&idEstrutura $=72 \&$ idMenu $=3813>$. Access in: set. 2010.
BUSTAMANTE, MMC., MARTINELLI, LA., SILVA, LA., CAMARGO, PB., KLINK,CA., DOMINGUES, TF. and SANTOS, RV., 2004. $15 \mathrm{~N}$ natural abundance in woody plants and soils of central Brazilian savannas (Cerrado). Ecological Applications, vol. 14, p. 200-213.

CAVALCANTI, JA., MESSIAS, AS., SILVA, MCL., MORAES, JF and LIRA, LRB., 1998. Avaliação da fertilidade dos solos de Pernambuco: resultados de 1997. In Proceedings of the XII Reunião Brasileira de Manejo e Conservação do Solo e da Água, 1998. Fortaleza: Sociedade Brasileira de Ciência do Solo. p. 365-366.

CHAGAS, CS., CARVALHO JUNIOR, W., BHERING, SB., TANAKA, AK. and BACA, JFM., 2004. Estrutura e organização do Sistema de Informações Georreferenciadas de Solos do Brasil (SIGSOLOS - versão 1.0). Revista Brasileira de Ciência do Solo, vol. 28 , p. 865-876.

Conselho Nacional da Reserva da Biosfera da Caatinga - CNRBC, 2004. Cenários para o bioma caatinga. Recife: Secretaria da Ciência, Tecnologia e Meio Ambiente - SECTMA. 283 p.

COSTA, CCA., DANTAS, IM., CAMACHO, RGV., SOUZA, AM. and SILVA, NF., 2007. Produção de serapilheira na Caatinga da Floresta Nacional do Açú-RN. Revista Brasileira de Biociências, vol. 5, p. 246-248. Suplemento 1

COSTA, TCC., ACCIOLY, LJO., OLIVEIRA, MAJ., BURGOS, N. and SILVA, FHBB., 2002. Phytomass mapping of the "Seridó caatinga" vegetation by the plant area and the normalized difference vegetation indeces. Scientia Agrícola, vol. 9, p. 707-715.

DANTAS, JS., 2003. Dinâmica da produção e decomposição de folhedo e ciclagem de nutrientes em um ecossistema de caatinga arbórea no Agreste da Paraíba. Areia: Universidade Federal da Paraíba. 37 p. Monografia de Graduação em Agronomia.

FARIA, SM. and LIMA, HC., 1998. Additional studies of the nodulation status of legume species in Brazil. Plant and Soil, vol. 200, p. 185-192. http://dx.doi.org/10.1023/A:1004365121077

FARIA, SM., FRANCO, AA., JESUS, RM., MENANDRO, MS., BAITELLO, JB., MUCCI, ESF., DOBEREINER, J. and SPRENT, JI., 1984. New nodulating legume trees from southeast Brazil. New Phytologist, vol. 98, p. 317-328. http://dx.doi. org/10.1111/j.1469-8137.1984.tb02742.x

FARIA, SM., LEWIS, GP., SPRENT, JI. and SUTHERLAND, JM., 1989. Occurrence of nodulation in the Leguminosae. New Phytologist, vol. 111, p. 607-619. http://dx.doi. org/10.1111/j.1469-8137.1989.tb02354.x

FARIA, SM., LIMA, HC., FRANCO, JB., MUCCI, ESF. and SPRENT, JI., 1987. Nodulation of legume trees from southeast Brazil. Plant and Soil, vol. 99, p. 347-356. http://dx.doi.org/10.1007/ BF02370880

FIDALGO, ECC., BENITES, VM., MACHADO, PLOA., MADARI, BE., COELHO, MR., MOURA, IB. and LIMA, CX., 2007. Estoque de carbono nos solos do Brasil. Rio de Janeiro: EMBRAPA Solos. 27 p.

FRAGA, VS. and SALCEDO, IH., 2004. Declines of organic nutrient pools in tropical semi-arid soils under subsistence farming. Soil Science Society of America Journal, vol. 68, p. 215-224.

FREITAS, ADS. and SAMPAIO, EVSB., 2008. Fixação biológica do N2 em leguminosas arbóreas da Paraíba e de Pernambuco. In MENEZES, RSC., SAMPAIO, EVSB. and SALCEDO, IH. Fertilidade do solo e produção de biomassa no semi-árido. Recife: Editora UFPE. p. 27-46. 
FREITAS, ADS., SAMPAIO, EVSB., MENEZES, RSC. and TIESSEN, H., 2010a. 15N natural abundance of non fixing woody species in the Brazilian dry forest (caatinga). Isotopes in Environmental and Health Studies, vol. 46, p. 210-218.

FREITAS, ADS., SAMPAIO, EVSB., SANTOS, CERS. and FERNANDES, AR., 2010b. Biological nitrogen fixation in tree legumes of the Brazilian semi-arid caatinga. Journal of Arid Environments, vol. 74, p. 344-349. http://dx.doi.org/10.1016/j. jaridenv.2009.09.018

FREITAS, MB., CHOUDHRURY, EM. and FARIA, CMB., 1981. Manejo e conservação de solo no Agreste Pernambucano. Petrolina: CPATSA/EMBRAPA. 44 p. Boletim de Pesquisa, no. 6.

GALVÃO, SJ. and CATE JUNIOR, R., 1969. Levantamento da fertilidade de solo do Nordeste. Recife: Instituto de Pesquisas e Experimentação Agropecuária do Nordeste. 14 p. $1^{\text {a }}$ Aproximação.

GARIGLIO, MA., SAMPAIO, EVSB., CESTARO, LA. and KAGEYAMA, P., 2010. Uso sustentável e conservação dos recursos florestais da caatinga. Brasília: Ministério do Meio Ambiente. p. 29-48.

GEHRING, C., VLEK, PLG., SOUZA, LAG. and DENICH, M. 2005. Biological nitrogen fixation in secondary regrowth and mature rainforest of central Amazonia. Agriculture, Ecosystems and Environment, vol. 111, p. 237-252. http://dx.doi.org/10.1016/j. agee.2005.06.009

GUIMARÃES, VA., CARVALHO, MSBS. and COSTA, RI., 1998. Levantamento da fertilidade do solo no estado do Ceará. In Proceedings of the XII Reunião Brasileira de Manejo e Conservação do Solo e da Água, 1998. Fortaleza: Sociedade Brasileira de Ciência do Solo. p. 53-54.

HANDLEY, LL., AUSTIN, AT., ROBINSON, D., SCRIMGEOUR, CM., RAVEN, JA., HEATON, THE., SCHMIDT, S. and STEWART, GR., 1999. The $15 \mathrm{~N}$ natural abundance (d 15N) of ecosystem samples reflects measures of water availability. Australian Journal of Plant Physiology, vol. 26, p. 185-199. http://dx.doi.org/10.1071/PP98146

HARDESTY, LH. and BOX, TW., 1988. Defoliation impacts on coppicing browse species in northeast Brazil. Journal of Range Management, vol. 41, p. 66-70. http://dx.doi.org/10.2307/3898793

HÖGBERG, P., 1997. 15N natural abundance in soil-plant systems. New Phytologist, vol. 137, p. 179-203. http://dx.doi. org/10.1046/j.1469-8137.1997.00808.x

Instituto Brasileiro do Meio Ambiente e dos Recursos Naturais Renováveis - IBAMA, 1992. Plano de manejo florestal para a Região do Seridó do Rio Grande do Norte. Natal. Projeto PNUD/ FAO/IBAMA.

JACOMINE, PKT., 1996. Solos sob caatinga - características e uso agrícola. In ALVAREZ, V., FONTES, LEF. and FONTES, MPF. (Eds.). O solo nos grandes domínios morfoclimáticos do Brasil e desenvolvimento sustentado. Viçosa: SBCS; UFV-DPS. p. $95-111$.

JACOMINE, PKT., ALMEIDA, JC. and MEDEIROS, LAR., 1973. Levantamento exploratório - Reconhecimento de solos do estado do Ceará. Recife: Divisão de Pesquisa Pedológica, Ministério da Agricultura. 455 p. Boletim técnico, no. 28.

JACOMINE, PKT., CAVALCANTE, AC., BURGO, N., PESSOA, SCP. and SILVEIRA, CO., 1972a. Levantamento exploratório - Reconhecimento de solos do Estado de Pernambuco. Recife: Centro de Pesquisa Pedológicas - Empresa Brasileira de Pesquisa Agropecuária, Ministério da Agricultura. 354 p. Boletim técnico, no. 35 .

JACOMINE, PKT., CAVALCANTE, AC., PESSOA, SCP. and SILVEIRA, CO., 1975a. Levantamento exploratório - Reconhecimento de solos do Estado de Alagoas. Recife: Centro de Pesquisa Pedológicas - Empresa Brasileira de Pesquisa Agropecuária, Ministério da Agricultura. 531 p. Boletim técnico, no. 35.

JACOMINE, PKT., CAVALCANTE, AC., SILVA, EFBR., MONTENEGRO, JO., FORMIGA, RA., BURGO, N. and MELO FILHO, HFR., 1979. Levantamento exploratório-Reconhecimento de solos da margem direita do rio São Francisco Estado da Bahia. Recife: Empresa Brasileira de Pesquisa Agropecuária, Ministério da Agricultura. 1296 p. Boletim técnico, no. 52.

JACOMINE, PKT., MONTENEGRO, JO., RIBEIRO, MR. and FORMIGA, RA., 1975b. Levantamento exploratório - Reconhecimento de solos do Estado de Sergipe. Recife: Centro de Pesquisa Pedológicas - Empresa Brasileira de Pesquisa Agropecuária, Ministério da Agricultura. 506 p. Boletim Técnico, no. 36.

JACOMINE, PKT., RIBEIRO, MR., MONTENEGRO, JO, SILVA, AP. and MELO FILHO, HFR., 1972b. Levantamento exploratório - Reconhecimento de solos do Estado da Paraíba. Rio de Janeiro: Equipe de Pedologia e Fertilidade do Solo, Ministério da Agricultura. 670 p. Boletim técnico, no. 15.

JACOMINE, PKT., SILVA, FBRE., FORMIGA, RA., ALMEIDA, JC., BELTRÃO, VA., PESSOA, SCP. and FERREIRA, RC., 1971. Levantamento exploratório - Reconhecimento de solos do Estado Do Rio Grande do Norte. Recife: Divisão de Pesquisa Pedológicas, Ministério da Agricultura. 531 p. Boletim técnico, no. 21.

JOHNSSON, RG., 1990. The interception, throughfall ad stemflow in a forest in highland Scoland and comparison with other upland forests in the UK. Journal of Hidrology, vol. 118, p. 281-287. http://dx.doi.org/10.1016/0022-1694(90)90263-W

KAUFFMAN, JB., SANFORD JUNIOR, RL., CUMMINGS, DL., SALCEDO, IH. and SAMPAIO, EVSB., 1993. Biomass and nutrient dynamics associated with slash fires in neotropical dry forests. Ecology, vol. 74, p. 140-151. http://dx.doi.org/10.2307/1939509

LEITE, LFC., 1998. Biomassa de raízes finas e fertilidade do solo, sob vegetação de caatinga em Caruaru-PE. Recife: Universidade Federal Rural de Pernambuco. 73 p. Dissertação de Mestrado em Ciência do Solo.

LEPRUN, JC., 1983. Relatório de fim de convênio de manejo e conservação do solo no nordeste brasileiro (1982-1983). Recife: SUDENE. 290 p.

LIMA, GFC., FARIAS, ME., ANDRADE, GC. and VASCONCELOS, SHL., 1985. Forrageiras para a pecuária norte-rio-grandense: pesquisas em pastagens desenvolvidas pela EMPARN. Natal: EMPARN. 33 p. Documentos, no. 15.

LIMA, PRA. and LEOPOLDO, PL., 2000. Quantificação de componentes hidrológica de uma mata ciliar, através do balanço de massas. Revista Árvore, vol. 24, p. 241-252.

MAIA, SMF., OLIVEIRA, TS. and OLIVEIRA, FN., 2004a. Plantas espontâneas em sistemas de manejo do solo na cultura do cajueiro. In MENDONÇA, ES., XAVIER, FAS., LIBARDI, PL., ASSIS JUNIOR, RN. and OLIVEIRA, TS. (Eds). Solo e água: aspectos de uso e manejo com ênfase no semi-árido nordestino. Fortaleza: Universidade Federal do Ceará. p. 176-199. 
MAIA, SMF., XAVIER, FAS., AGUIAR, MI., OLIVEIRA, TS., MENDONÇA, ES. and ARAÚJO FILHO, JA., 2004b. Sistemas agroflorestais no trópico semi-árido cearense. In MENDONÇA, ES., XAVIER, FAS., LIBARDI, PL., ASSIS JUNIOR, RN. and OLIVEIRA, TS. (Eds.). Solo e água: aspectos de uso e manejo com ênfase no semi-árido nordestino. Fortaleza: Universidade Federal do Ceará. p.105-129.

MARGOLIS, E., SILVA, AB. and JACQUES, FO., 1985b. Determinação dos fatores da equação universal de perdas de solo para as condições de Caruaru (PE). Revista Brasileira de Ciência do Solo, vol. 9, p. 165-169.

MARGOLIS, E., SILVA, AB. and REIS, OV., 1985a. Controle da erosão com diferentes práticas conservacionistas num solo litólico de Caruaru (PE). Revista Brasileira de Ciência do Solo, vol. 9, p. 61-164.

MARTINELLI, LA., PICCOLO, MC., TOWNSEND, AR., VITOUSEK, PM., CUEVAS, E., MCDOWELL, W., ROBERTSON, GP., SANTOS, OC. and TRESEDER, K., 1999. Nitrogen stable isotopic composition of leaves and soil: tropical versus temperate forests. Biogeochemistry, vol. 46, p. 45-65. http:// dx.doi.org/10.1007/BF01007573

MARTINS, CM., GALINDO, ICL., SOUZA, EA., POROCA, HA., ANDRADE, FM., ANDRADE, BMT., ALMEIDA NETO, LA. and LIMA, JFWF., 2008. Fracionamento físico da serrapilheira presente em áreas em processo de degradação no semiárido pernambucano. In Proceedings of the XVII Reunião Brasileira de Manejo e Conservação do Solo e da Água, 2008. Rio de Janeiro: UFRRJ; Embrapa Solos; Embrapa Agrobiologia. CD-ROM.

MEDEIROS, EV., 1999. Variação sazonal na biomassa de raízes finas sob vegetação de caatinga. Recife: Universidade Federal Rural de Pernambuco. 48 p. Dissertação de Mestrado em Ciência do Solo.

MENEZES, RCS. and SAMPAIO, EVSB., 2000. Agricultura sustentável no semi-árido nordestino. In OLIVEIRA, TS., ROMERO, RE., ASSIS JUNIOR, RN. and SILVA, JRCS. (Eds.). Agricultura, sustentabilidade e o semiárido. Fortaleza: Sociedade Brasileira de Ciência do Solo; Universidade Federal do Ceará. p. 20-46.

MENEZES, RCS. and SAMPAIO, EVSB., 2002. Simulação dos fluxos e balanços de fósforo em uma unidade de produção agrícola familiar no Agreste Paraibano. In PETERSEN, P. and SILVEIRA, LM. (Eds.). Agroecologia e agricultura familiar no semi-árido: avanços a partir do Agreste da Paraíba. Rio de Janeiro: AS-PTA. p. 249-260.

MENEZES, RSC., TIESSEN, H., SILVEIRA, LM., ANDRADE, L., SAMPAIO, EVSB., SALCEDO, IH., SABOURIN, E., PORTO, I. and SARMENTO, C., 2002. Balanços de nutrientes em unidades de produção agrícola familiar no Agreste e Curimataú da Paraíba: avaliação e resultados preliminares. In PETERSEN, P. and SILVEIRA, LM. (Eds.). Agroecologia e agricultura familiar no semi-árido: avanços a partir do Agreste da Paraíba. Rio de Janeiro: AS-PTA. p. 235-247.

MENEZES, RSM., GARRIDO, MS. and PEREZ-MARIN, AM., 2005. Fertilidade dos solos no semi- árido. In Proceedings of the XXX Congresso Brasileiro de Ciência do Solo, 2005. Recife: Sociedade Brasileira de Ciência do Solo. 30 p. CD-ROM.

MORAIS, GM., SARAIVA, JPB., FREITAS, HHS., OLIVEIRA, TS., MENDONÇA, ES. and CRISOSTOMO, LA., 2004. Aporte de matéria orgânica e nutrientes em sistemas de manejo do solo na cultura do cajueiro. In MENDONÇA, ES., XAVIER, FAS.,
LIBARDI, PL., ASSIS JUNIOR, RN. and OLIVEIRA, TS. (Eds.). Solo e água: aspectos de uso e manejo com ênfase no semi-árido nordestino. Fortaleza: Universidade Federal do Ceará. p. 156-175.

OLIVEIRA, LB., SILVA, FBR., ALMEIDA, JC., PARAHYBA, RBV., SÁ, RF. and LESSA, ASN., 1988. Condições fitoedafoclimáticas do Nordeste. Recife: EMBRAPA-SNLCS. Parte III - Níveis de necessidade de calcário e de carências de potássio e de fósforo para os solos do Nordeste do Brasil.

OLIVEIRA JUNIOR, JC. and DIAS, HCT., 2005. Precipitação interna de um fragmento secundário de mata atlântica no município de Viçosa, MG. Revista Árvore, vol. 29, p. 9-15.

PEREZ-MARIN, AM. and MENEZES, RSC., 2008. Ciclagem de nutrientes via precipitação pluvial total, interna e escoamento pelo tronco em sistema agroflorestal com Gliricidia sepium. Revista Brasileira de Ciência do Solo, vol. 32, p. 2573-2579. http://dx.doi. org/10.1590/S0100-06832008000600034

QUEIROZ, LP., 2002. Distribuição das espécies de Leguminosae na Caatinga. In SAMPAIO, EVSB., GIULIETTI, AM., VIRGÍNIO, J. and GAMARRA-ROJAS, C. (Eds.). Vegetação e flora da Caatinga. Recife: APNE/CNIP. p. 141-153.

REDDY, SJ., 1983. Climatic classification: the semi-arid tropics and its environment - a review. Pesquisa Agropecuária Brasileira, vol. 18 , p. $23-847$

RIBEIRO, KA., MAIA, SMF., SOUSA, HHF., CAMELO, AM., OLIVEIRA, TS., MENDONÇA, ES. and CRISOSTOMO, LA., 2004. Manejo do solo na cultura do cajueiro anão-precoce no município de Pacajus - CE. In MENDONÇA, ES., XAVIER, FAS., LIBARDI, PL., ASSIS JUNIOR, RN. and OLIVEIRA, TS. (Eds.). Solo e água: aspectos de uso e manejo com ênfase no semi-árido nordestino. Fortaleza: Universidade Federal do Ceará. p. 132-155.

ROGGY, JC., PREVOST, MF., GOURBIERE, F., CASABLANCA, H., GARBAYE, J. and DOMENACH, AM., 1999. Leaf natural 15N abundance and total $\mathrm{N}$ concentration as potential indicators of plant $\mathrm{N}$ nutrition in legumes and pioneer species in a rain forest of French Guiana. Oecologia, vol. 120, p. 171-182. http://dx.doi. org/10.1007/s004420050846

SALCEDO IH., SAMPAIO, EVSB. and ARAUJO, MSB., 1993. Mudanças no $\mathrm{C}, \mathrm{N}$ e $\mathrm{P}$ do solo causadas por queimadas. In. Proceedings of the XXIV Congresso Brasileiro de Ciência do Solo, 1993. Goiana: Sociedade Brasileira de Ciência do Solo. p. $177-178$.

SALCEDO, IH., LEITE, L., VASCONCELOS, E., SOUZA, F. and SAMPAIO, EVSB., 1999. Produção de raízes finas sob vegetação de caatinga. Proccedings of the Workshop Sobre Sistema Radicular: metodologias e estudos de caso, 1999. Aracaju: EMBRAPA. p.139-152.

SALCEDO, IH., TIESSEN, H. and SAMPAIO, EVSB., 1997. Nutrient availability in soil samples from shifting cultivation sites in the semi-arid Caatinga of NE Brazil. Agriculture, Ecosystems and Environment, vol. 65, p. 177-186. http://dx.doi.org/10.1016/ S0167-8809(97)00073-X

SAMPAIO, EVSB., 1995. Overview of the Brazilian caatinga. In BULLOCK, SH., MOONEY, HA. and MEDINA, E. (Eds.). Seasonally dry tropical forests. Cambridge: Cambridge University Press. p. 35-63.

-, 1996. Fitossociologia. In SAMPAIO, EVSB., MAYO, SJ. and BARBOSA, MRV. (Eds.). Pesquisa botânica nordestina: progresso e perspectivas. Recife: Sociedade Botânica do Brasil. p. 203-224. 
SAMPAIO, EVSB. and MENEZES, RSC., 2002. Perspectivas de uso do solo no semiárido nordestino. In ARAÚJO, QR. (Ed.). 500 anos de uso do solo no Brasil. Viçosa: Sociedade Brasileira de Ciência do Solo. p. 339-363.

SAMPAIO, EVSB. and SALCEDO, IH., 1997. Diretrizes para o manejo sustentável dos solos brasileiros: região semi-árida. In Proceedings of the XXVI Congresso Brasileiro de Ciência de Solo, 1997. Rio de Janeiro: Sociedade Brasileira de Ciência de Solo. 33 p. CD-ROM.

SAMPAIO, EVSB. and SILVA, GC., 1996. Ciclagem de nutrientes. In SAMPAIO, EVSB., MAYO, SJ. and BARBOSA, MRV. (Eds.). Pesquisa botânica nordestina: progressos e perspectivas. Recife: Sociedade Botânica do Brasil, Seção Regional de Pernambuco. p. 191-202.

SAMPAIO, EVSB., ARAÚJO, EL., SALCEDO, IH. and Tiessen, H., 1998. Regeneração da vegetação de caatinga após corte e queima, em Serra Talhada, PE. Pesquisa Agropecuária Brasileira, vol. 33, p. 621-632.

SAMPAIO, EVSB., ARAÚJO, MSB., SALCEDO, IH. and MENEZES, RSC., 2009. Manejo sustentável do semi-árido nordestino. Recife: Editora Universitária. 149 p.

SAMPAIO, EVSB., SALCEDO, IH. and SILVA, FBR., 1995. Fertilidade de solos do semi-árido do Nordeste. In PEREIRA, JR. and FARIA, CMB. (Eds.). Fertilizantes: insumo básico para a agricultura e combate à fome. Petrolina, EMBRAPA-CPATSA/ SBCS. p. 51-71.

SAMPAIO, EVSB., TIESSEN, H., ANTONINO, ACD. and SALCEDO, IH., 2004. Residual N and P fertilizer effect and fertilizer recovery on intercropped and sole-cropped corn and bean in semiarid northeast Brazil. Nutrient Cycling in Agroecosystems, vol. 70, p. 1-11. http://dx.doi.org/10.1023/B:FRES.0000049356.83427.93

SANCHEZ, PA., 2002. Soil fertility and hunger in África. Science, vol. 295 , p. $2019-2020$.

SANTANA, JAS., 2005. Estrutura fitossociológica, produção de serapilheira e ciclagem de nutrientes em uma área de caatinga no Seridó do Rio Grande do Norte. Areia: Universidade Federal da Paraíba. 184 p. Tese de Doutorado em Agronomia.

SCHACHT, WH., MESQUITA, RCM., MALECHEK, JC. and KIRMSE, RD. 1989. Response of Caatinga vegetation to decreasing levels of canopy cover. Pesquisa Agropecuáqria Brasileira, vol. 24, p.1421-1426.

SCHULZE, ED., GEBAUER, G., ZIEGLER, H. and LANGE, OL., 1991. Estimates of nitrogen fixation by trees on an aridity gradient in Namibia. Oecologia, vol. 88, p. 451-455. http://dx.doi. org/10.1007/BF00317592

SILVA, FBR., RICHE, GR., TONNEAU, JP., SOUZA NETO, NC., BRITO, LTL., CORREIA, RC., CAVALCANTE, AC., SILVA, AB., ARAUJO FILHO, JC. and LEITE, AP., 1993. Zoneamento agroecológico do Nordeste: diagnóstico do quadro natural e agrossocioeconômico. Petrolina: EMBRAPA-CPATSA. 325 p.
SILVA, GC., 1998. Relações alométricas de dez espécies vegetais e estimativas de biomassas aéreas da caatinga. Recife: Universidade Federal Rural de Pernambuco. 163 p. Tese de Doutorado em Botânica.

SILVA, IF., ANDRADE, AP., CAMPOS FILHO, OR. and OLIVEIRA, FAP., 1986. Efeito de diferentes coberturas vegetais e práticas conservacionistas no controle da erosão. Revista Brasileira de Ciência do Solo, vol. 10, p. 289-292.

SILVA, JRC., 2000. Erosão e produtividade do solo no semi-árido. In OLIVEIRA, TS., ROMERO, RE., ASSIS JUNIOR, RN. and SILVA, JRCS. (Eds.). Agricultura, sustentabilidade e o semiárido. Fortaleza: Sociedade Brasileira de Ciência do Solo; Universidade Federal do Ceará. p. 168-213.

SILVA, VM., ARAÚJO FILHO, JA., LEITE, ER., PEREIRA, VLA. and UGIETTE, SA., 1995. Manipulação da caatinga e seu efeito sobre parâmetros fitossociológicos e de produção, em Serra Talhada, Pernambuco. In Proceedings of the XXXII Reunião da Sociedade Brasileira de Zootecnia, 1995. Brasília: Sociedade Brasileira de Zootecnia. p. 58-61.

SOUTO, PC., 2006. Acumulação e decomposição da serapilheira e distribuição de organismos edáficos em área de caatinga na Paraíba, Brasil. Areia: Universidade Federal da Paraíba. 150 p. Tese de Doutorado em Agronomia.

SOUZA, LAG., SILVA. MF. and MOREIRA, FW., 1994. Capacidade de nodulação em cem leguminosas da Amazônia. Acta Amazônica, vol. 24, p. 9-18.

SOUZA, LQ., 2010. Fitossociologia em áreas com diferentes históricos de uso e fixação biológica de nitrogênio em caatinga madura na Paraíba. Recife: Universidade Federal de Pernambuco. Dissertação de Mestrado em Ciência e Tecnologia Nuclear.

SPRENT, JI., GEOGHEGAN, IE., WHITTY, PW. and JAMES, EK., 1996. Natural abundance of $15 \mathrm{~N}$ and $13 \mathrm{C}$ in nodulated legumes and other plants in the cerrado and neighbouring regions of Brazil. Oecologia, vol. 105, p. 440-446. http://dx.doi. org/10.1007/BF00330006

The Bean Bag, 1995. Royal Botanic Gardens, Kew. Available from: $<$ http://www.rbgkew.org.uk/herbarium/legumes/beanbag.html>.

The Bean Bag, 1996. Royal Botanic Gardens, Kew. Available from: <http://www.rbgkew.org.uk/herbarium/legumes/beanbag.html>.

The Bean Bag, 1997. Royal Botanic Gardens, Kew. Available from: $<$ http://www.rbgkew.org.uk/herbarium/legumes/beanbag.html>.

The Bean Bag, 2002. Royal Botanic Gardens, Kew. Available from: $<$ http://www.rbgkew.org.uk/herbarium/legumes/beanbag.html>.

TIESSEN, H., SALCEDO, IH. and SAMPAIO, EVSB., 1992. Nutrient and soil organic matter dynamics under shifting cultivation in semi-arid northeastern Brazil. Agriculture, Ecosystems and Environment, vol. 38, p. 139-151. http://dx.doi.org/10.1016/01678809(92)90139-3 